I. V. ZENKOV'1, Professor, Doctor of Engineering Sciences, Honored Ecologist of the Russian Federation, zenkoviv@mail.ru

V. V. ZAYATS ${ }^{2}$, Candidate for a Master's Degree

B. N. NEFEDOV ${ }^{3}$, Candidate of Engineering Sciences

N. B. NEFEDOV ${ }^{3}$, Post-Graduate Student

${ }^{1}$ Siberian Federal University, Krasnoyarsk, Russia

${ }^{2}$ Academician Reshetnev Siberian State University for Science and Technology. Krasnoyarsk, Russia

3/nstitute of Computational Technologies, Novosibirsk, Russia

\title{
EARTH REMOTE SENSING IN ECOLOGICAL EVALUATION OF DISTURBED LANDS IN SOUTH YAKUTIA
}

\section{Introduction}

Currently the Republic of Sakha (Yakutia), with its unique mineral resources, is among the advanced development territories in the Russian Federation. From the one hand, the severe and long winters with the temperatures down to $-60^{\circ} \mathrm{C}$ require sustainable operation of the heating energy sector, at the minimum risk of emergencies; on the other hand, the large power-generating and coking coal fields available in the south of the Republic predetermine large-scale mineral mining operations. In the close vicinity of Neryungri, extraction of fossil coal from the unique Neryungri deposit has been carried out for more than 40 years; and near Chulman settlement, small-size open casts operate at coal outcrops under alluvium in Chulmakan and Denisovskoe fields since 2000.

In view of the mining completion at Neryungri open pit mine and with regard to the increased production of coal at the small-size open casts, it is necessary to study condition of landscape in the mining areas and, if required, to work out recommendations on ecological improvement of the mining-disturbed lands. The studies into the environmental after-effects of coal mining and the practical recommendations on elimination of the related problems are in the scope of activities of both the Russian and foreign ecologists [1-14].

\section{Investigation results}

Geologically, Neryungri deposit is composed of 20 beds of different rank coal (coking coal grades $2 \mathrm{KV}, 2 \mathrm{KSV}$; lowcaking coal grade 3SS). The deposit is a downfold field with an area of $6 \mathrm{~km}^{2}$ and the maximum occurrence depth of 320 $\mathrm{m}$ in center. The richest coal-bearing strata contain Moshchny bed having the average thickness of $26.5 \mathrm{~m}$ and the maximum thickness of $120 \mathrm{~m}$. At the present day, mining is carried out at the southern end of the downfold. Within a radius of $20 \mathrm{~km}$ from Chulman settlement $20 \mathrm{~km}$ northeastwards Neryungri town, coal is produced at Chulmakan and Denisovskoe deposits (fat coal grades $\mathrm{ZH}, \mathrm{KZH}$; coking coal grades $\mathrm{K}, 1 \mathrm{KV}, 2 \mathrm{KV}$ ). Mining is conducted since the late 1990s down the dip of coal beds at the outcrops under alluvium. Across the whole area of the deposits, the overlying thickness of of young trees.
In the south of the Republic of Sakha (Yakutia), coal is produced by Ner yungri open pit mine and small open cuts. At Neryungri open pit mine, coal is ex tracted at the end of a downfold at a depth of 300-320 m. At the small open cuts, carried out at the coal outcrops under alluvium and is advanced down he dip of the coal beds. At the present time, all small open casts have the depth sessment of the coal mining sites shows that the land is disturbed across the area of $5000 \mathrm{ha}$. The further environmental analysis of the mining landscape uses the pit mine and small open casts, respectively. The open pit coal mining operation in the south of the Republic of Sakha (Yakutia) have resulted in the disturbance the natural landscape over the overall area of $5662.3 \mathrm{ha}$. The lack of the plant cover across the whole area of the disturbed land is explained the presence of the of coal bodies with the mean annual temperatures of $-7 . . .-8^{\circ}$ and by the absence of reclamation activities. That low factors of the environmental equilibrium safety are intolerable. For this reason, a package of activities has been recommended for mediation of the disturbed land with the planting of larch-trees at overburden a The planting requires application of much quantities of fertilizes contain-

Key words: South Yakutia, small open casts, mining production landscape, vegeta eco-system development, earth remote sensing, disturbed land reclamation

DOI: $10.17580 /$ em.2017.02.12

overburden rocks is 3-6 $\mathrm{m}$. Coal beds have a complex structure, are to $7 \mathrm{~m}$ thick and occur at an angle of $3-10^{\circ}$.

Recently, Neryungri open pit mine is divided into two independent sub-mines with their highwalls advanced toward each other, in the northern and southern directions; the volume of stripping reduces every year at the stable annual coal output at the level of $10 \mathrm{Mt}$. By the moment of satellite imaging, Neryungri operated mining and transportation equipment described below [15]. Blasthole drilling used four drill rigs SBSH-250. Overburden removal and coal excavation was implemented using 7 hydraulic forward-acting excavators with the bucket capacity of $15-18 \mathrm{~m}^{3}$, two draglines ESH-11/70 and four mine excavators EKG-20. The excavators operated together with 40 dump trucks with a capacity of 120-320 t. Given that equipment, the open pit mine had a capacity of $10 \mathrm{Mt}$ in terms of coal production and $12 \mathrm{Mm}^{3}$ in terms of overburden removal. The standby equipment stored at the open pit mine infrastructure site included 40 dump trucks of the same type, one mine excavator EKG-32, one mine excavator EKG-18 and a hydraulic forward-acting shovel with the bucket capacity of 16-18 $\mathrm{m}^{3}$. 

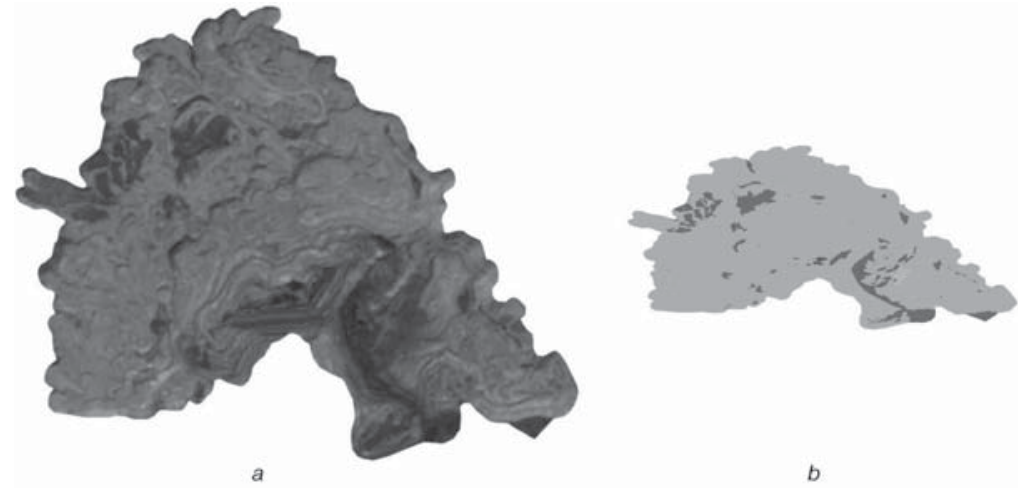

Fig. 1. Satellte sub-images of the area of Neryungri OPM in July 2016 a-image prepared for the interpretation;

$b$-the same image with the interpretation results

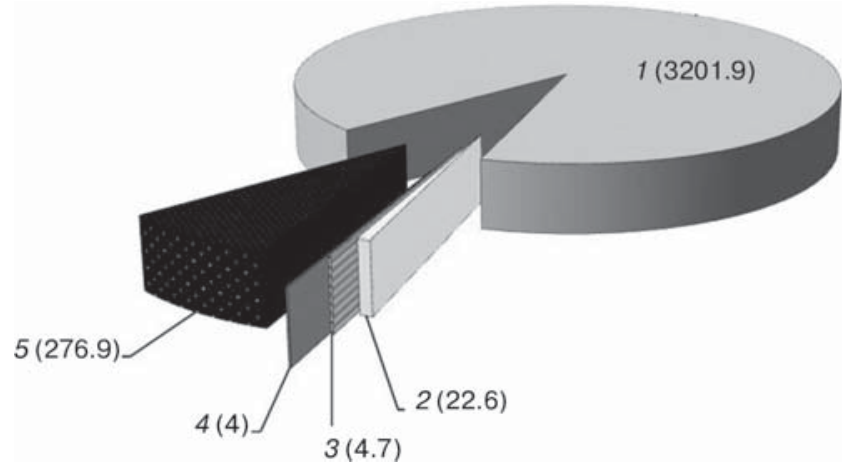

Fig. 2. Structure of land (ha) under mining and areas with eco-system at overburden dumps according to the disturbed landscape classification at Neruyngri OPM (July 2016): 1-areas of mine workings and overburden dumps without plant cover; 2-areas with the recovering plant cover; 3-areas under shrub vegetation; 4-production-made water bodies; 5-opened-up or extracted coal beds

The small open casts have a mining front of $45.2 \mathrm{~km}$ of the total length at the depth of the pits in the range of 20$50 \mathrm{~m}$. The contours of the highwalls follow the contours of the coal outcrops under alluvium. By the time of the satellite imaging, the small open casts had seven drill rigs SBSH-250 used to drill blastholes. Stripping and coal excavation was carried out by 20 mine excavators of the type of EKG and EG with the bucket capacities of $2.5-8 \mathrm{~m}^{3}$. The excavators were serviced by 80 dump trucks with a capacity of $25-55 \mathrm{t}$. All in all, coal output at the open pit sub-mines made $3 \mathrm{Mt}$ at the overburden removal at the level of $7 \mathrm{Mm}^{3}$.

By the authors' estimates, the operation of Neryungri open pit and open casts has altered the natural eco-system in the area of more than 5000 ha. The integrated evaluation of the ecological balance in the coal mining area is obtained from the comparison of the data on natural landscape prior to open pit coal mine and the figure of the mining-disturbed landscape with the cuts and dumps. The authors have generalized the available information of the natural climate and soil-and-cover complex with the purpose of comparing this information and the satellite observation data [16].

South Yakutia is a territory of mountain ridges, zones of bold mountains, plateaus and bowls having complex geology and varied geomorphology. Medium- and highlands prevail with the altitudes in the range from 650 to $2420 \mathrm{~m}$. The best part of the area is the Aldan Upland with the altitude of $800-1200 \mathrm{~m}$. The climate in the south of Yakutia, accommodating the Neryungri Region, is governed by the mountain relief and interacting weather-forming factors, and is assumed the extreme continental climate. Winter is long (7-7.5 months), cold and brings little snow. In winter, the entire area in question is subjected to high barometric pressure anticyclones, with very low temperatures in the ground layer (from $-40^{\circ}$ to $-50^{\circ}$ ). The incoming Siberian anticyclones are permanent and very dry. Considerable warming is possible under the eastern wind blowing from the sea side of the Pacific Ocean that causes warm air inflow and precipitation. The average winter temperature is $-32^{\circ}$.

The suburbs of Neryungri experience considerable precipitates yearly, even in the driest month. The average annual temperature in Neryungri is $7.2^{\circ}$. The annual precipitates make $557 \mathrm{~mm}$. Summer is short, moderately worm and rainy. The climate in South Yakutia is also affected by the southern cyclones from the Near-Baikal Area and Mongolia. In these periods, temperature raises to $34-38^{\circ}$. Under invasion of the Arctic air, the average daily temperature can drop below $10^{\circ}$. The average summer temperature is $17-19^{\circ}$.

A feature of the natural landscape intrinsic to the territory of Yakutia and governing its image in many ways is permafrost (permafrost zone). The depth of freezing in winter ranges between 0.3 and $4 \mathrm{~m}$, and depends on the vegetation, humidity, relief and the elevation of an area. In the region under study, in the frozen bleached highlands over $600 \mathrm{~m}$ high, humic calcareous soil predominates inasmuch as it is formed in the conditions of permafrost and frigid climate of South Yakutia. By vegetation type, South Yakutia falls into a sub-zone of middle boreal forest. The mountain relief governs the vertical zonal distribution of the plant cover in the region, with the characteristic abrupt change between different groups and types of vegetation often dissimilar in ecology and origination.

The lowest areas (altitude of 650-900 m) are covered with mountain middle boreal forest. The main forest-forming species in such type taiga are first of all larch-trees, pines and fir trees. The shrub layer is composed of mountain ashes, big willows, alders, shrub birch and mountain pines. The moss and lichen covers reach thickness of $20-25 \mathrm{~cm}$. Dwarf shrubs and grass are present in ample amount: ledum, clusterberry, juniper etc.

The recovery of the ecological equilibrium in the industrial landscape of the mentioned open pit mines was assessed using satellite surveying results. Fig. 1 shows the satellite sub-images with the distinguished boundaries and classes of the disturbed land.

Aiming to refine the eco-system formation mechanism, the authors divide the mining landscape into five classes: opened-up coal beds prepared for mining; mine workings and dumps without plant cover; production-formed water bodies; areas with the recovering plant cover; shrub vegetation (Fig. 2).

The analysis of Fig. 2 makes it possible to draw a conclusion that the revegetation coefficient-a key component 

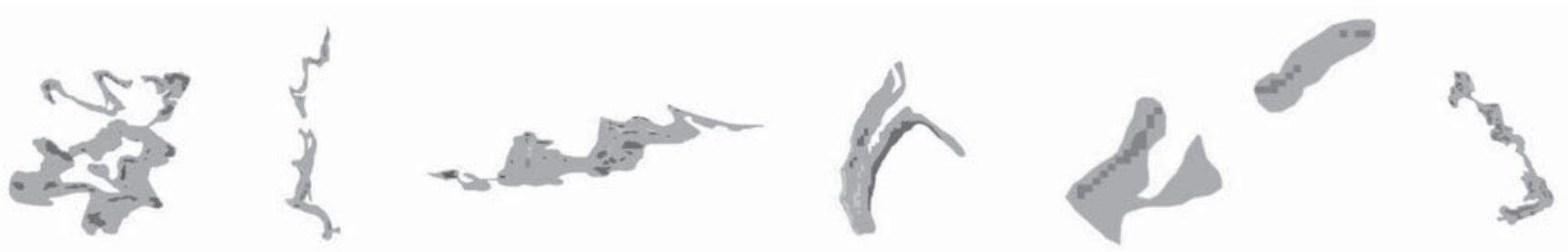

a
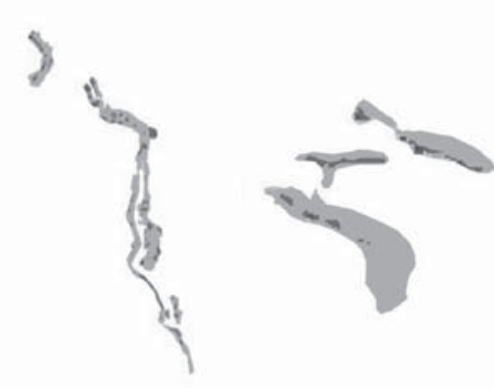

$b$
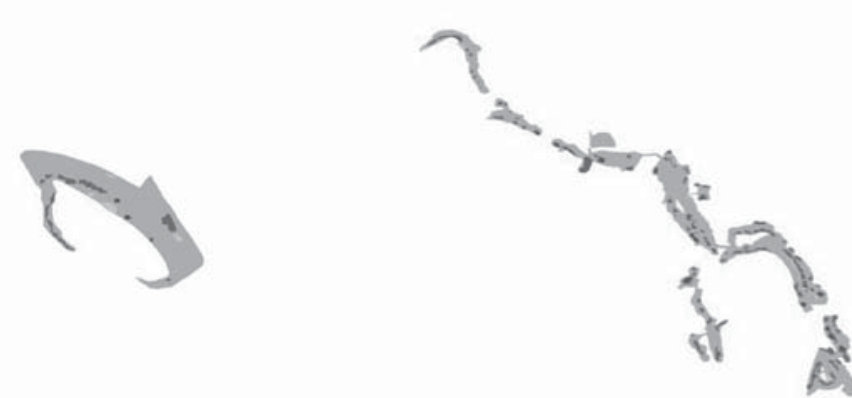

$c$

Fig. 3. Sub-images of disturbed lands at the small open casts with the interpretation results (July 2016): $a-$ Chulmakan North; $b$ - Chulmakan West; $c-$ Chulmakan South

of any eco-system-is very low in South Yakutia under conditions of the extreme continental climate and permafrost-0.012. This means that the special reclamation activities were never performed at the overburden dumps and the vegetation cover is only formed in the area of $31.3 \mathrm{ha}$, which makes $1.2 \%$ of the whole area of the mining-disturbed land. The sites of the forming plant cover occur in the areas where dumping was stopped more than 20 years ago.

In order to understand eco-system formation on the mining-disturbed landscape at the small open casts, 6 classes of mining lands are distinguished in the satellite images: opened-up and prepared coal beds; mine workings and overburden dumps without the plant cover; grass, shrubs and plants; production-made water bodies (Fig. 3).

The structure of lands under mining operations and generated by eco-systems at the small-size open casts in South Yakutia is shown in Fig. 4.

The revegetation coefficient is 0.029 . This means the lack of reclamation in the areas of dumping. The plant cover is only formed in the area of 61.9 ha, which makes $2.9 \%$ of the whole area of the mining-disturbed land.

In this manner, it has been found that within the area of 5623.3 ha of the land disturbed by open pit coal mining operations in South Yakutia, the generated vegetation mantle covers $1.66 \%$ of the whole disturbed land, which means that all vegetation species are present in the area of 93.2 ha.

Based on the afore-mentioned facts, an intermediate conclusion is drawn about the formation conditions of the mining-disturbed landscape and about the safety of the environmental equilibrium in the lands subjected to open pit coal mining. When coal beds have complex geological structure, stripping brings considerable volumes of gangue and low-quality coal on the surface of overburden dumps. By the authors' opinion, such mixture is of little use for generation of any vegetation cover on it. Furthermore, the geographical location of the mining areas in the permafrost zone dictates

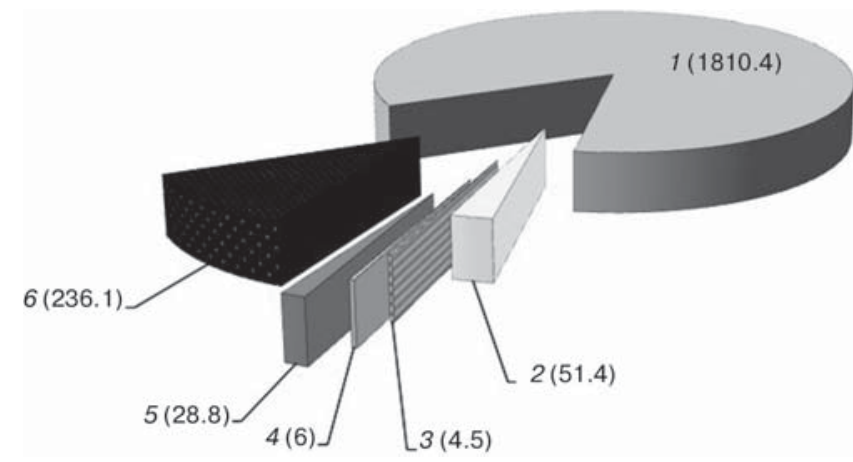

Fig. 4. Structure of land (ha) under mining and areas with eco-system at overburden dumps according to the disturbed landscape classification at the small open casts in South Yakutia (July 2016):

1-areas of mine workings and overburden dumps without plant cover; 2-areas with grass cover; 3-areas under shrub vegetation; 4-areas under tree vegetation; 5-production-made water bodies; 6-opened-up or extracted coal beds

essential deceleration of development of the vegetation. It is noteworthy that the open pit coal mines in the area of South Yakutia occur under extremely severe climatic conditions from the view of the vegetation eco-system recovery as compared with the open pit coal mines situated southwards the discussed territory in the Russian Federation, which is proved by the long-term research implemented by the authors of this article.

Thus, in the summery of the research, the common feature for the open pit coal mines in South Yakutia is the lack of the special reclamation activities on the mining-disturbed land and, as a consequence, the low recovery factors of the eco-systems at all open pit coal mines without exception. 
Such situation is in the authors' opinion impressible from the standpoint of the environmental equilibrium preservation in the areas with the long-delayed revegetation. Under the similar conditions in Polar Canada, there exists the positive experience on reclamation of land disturbed by open pit diamond mining, which proves efficiency of mechanical and biological reclamation. The special remediation activities on the miningdisturbed land with due regard to the natural climate conditions should follow the sequence presented below:

-removal of topsoil to the full depth by a dozer and placement of it on a temporary storage site (second decade of July);

-loading of the stored topsoil on dump trucks by shovels to be transported to overburden dumps (second decade of July at a lag of 2-3 days relative to the topsoil removal operations);

- spreading of the topsoil on dumps by a dozer (third decade of July with a delay by $3-4$ days relative to the topsoil transportation operations);

- plowing of the spread top soil to a depth of $18-20 \mathrm{~cm}$ with the simultaneous seeding of perennial grasses and application of large quantities of composite fertilizers containing azote, kalium and phosphorus (first decade of August);

-next year after the activities described above: planting of local species of shrubs and trees (the authors recommend larch-tree as the best species for the conditions of the southern areas of Yakutia);

-annual care and protection of the young plants for 5-7 years.

\section{Conclusions}

Considering natural climate and the presence of thick permafrost in the area of South Yakutia, it is required to adhere to recommendations on favorable conditions for vegetation development, based on the biological reclamation with planting and further perennial care of aboriginal species of shrubs and tree. Ecologically, the recommendations made with regard to the international experience of land reclamation under the same weather conditions should be duly included in coal mine planning and design since the increase in the open pit mining of coal in the nearest future will inevitably result in formation of mining landscape with the longterm absence of any vegetation cover.

References

1. Dvurechenskiy V. G., Androkhanov V. A. Soil-ecological state of technogenic landscapes of Novokuznetsk industrial complex. Zhivye i biokosnye sistemy. 2017. No. 20. pp. 3-7.

2. Zenkov I. V., Yuronen Yu. P., Nefedov B. N., Vokin V. N. Monitoring of ecosystem formation at open pit mines and waste dumps in the area of Bazhenovsky asbestos deposit by means of the earth remote sensing. Gornyi Zhurnal. 2017. No. 3. pp. 81-85. DOI: 10.17580/gzh.2017.03.15

3. Zenkov I. V., Yuronen Yu. P., Nefedov B. N., Baradulin I. M. Remote sensing in estimation of forest ecosystem generation at crushed stone quarries in Siberia. Eurasian mining. 2016. Vol. 1. pp. 50-54. DOI: 10.17580/em.2016.01.09

4. Zenkov I. V., Yuronen Yu. P. Nefedov B. N. Results of monitoring of vegetative ecosystem formation in abandoned places of Raychikhinskoe brown coal deposit using the distant sounding resources. Ekologiya i promyshlennost Rossii. 2017. Vol. 21, No. 2. pp. 28-33.

5. Schastlivtsev E. L., Yukina N. I., Kharlampenkov I. E. Informationanalytical system of geoecological monitoring of water resources in mining region. Vestnik Kuzbasskogo gosudarstvennogo tekhnicheskogo universiteta. 2016. No. 2(114). pp. 157-165.

6. Sokolov D. A., Androkhanov V. A., Kulizhskii S. P., Loiko S. V., Domozhakova E. A. Morphogenetic diagnostics of soil formation on tailing dumps of coal quarries in Siberia. Eurasian soil science. 2015. Vol. 48(1). pp. 95-105.

7. Naeth M. A., Wilkinson S. R. Establishment of Restoration Trajectories for Upland Tundra Communities on Diamond Mine Wastes in the Canadian Arctic. Restoration Ecology. 2014 Vol. 22(4). pp. 534-543.

8. Sena K., Barton C., Hall S., Angel P., Agouridis C., Warner R. Influence of spoil type on afforestation success and natural vegetative recolonization on a surface coal mine in Appalachia, United States. Restoration Ecology. 2015. Vol. 23(2). pp. 131-138.

9. Ngugil M. R., Neldner V. J., Doley D., Kusy B., Moore D., Richter $\mathrm{C}$. Soil moisture dynamics and restoration of self-sustaining native vegetation ecosystem on an open-cut coal mine. Restoration Ecology. 2015. Vol. 23(5). pp. 615-624.

10. Brady J. K. Salamander diversity of reforested abandoned surface coal mines in the Appalachian Region, U.S.A. Restoration Ecology. 2016. Vol. 24, Iss. 3. pp. 398-405.

11. Strunk S., Houben B., Krudewig W. Controlling the Rhenish opencast mines during. World of Mining - Surface \& Underground. 2016. Vol. 68(5). pp. 289-300.

12. Gilland K. E., McCarthy B. C. Microtopography Influences Early Successional Plant Communities on Experimental Coal Surface Mine Land Reclamation. Restoration Ecology. 2014. Vol. 22(2). pp. 232-239.

13. Knapp S., Gerth A., Stefan K. Sustainable recultivation and wastewater treatment in Vietnamese coal mining. World of Mining - Surface \& Underground. 2012. Vol. 64(4). pp. 253-263.

14. Kulik L., Stemann H. Ecology and biodiversity protection in the Rhenish lignite mining area. World of Mining - Surface \& Underground. 2014. Vol. 66(3). pp. 143-152.

15. Google Planet Earth. Available at: https://www.google.com/ earth/ (accessed: 9.10.2017).

16. Available at: https://earthexplorer.usgs.gov/ 